\title{
Serum Thyroid Stimulating Hormone Screening and Influence of Perinatal Factors
}

\author{
Sudhakar Palanisamy ${ }^{1}$ (D) $\cdot$ Ramesh Srinivasan $^{1}$ (D) $\cdot$ Suvetha Kannappan $^{2}$ (D) $\cdot$ JayaChandran Ganesan $^{3}$ (I)
}

Received: 17 January 2020 / Accepted: 15 January 2021 / Published online: 30 January 2021

(C) Dr. K C Chaudhuri Foundation 2021

To the Editor: Congenital hypothyroidism $(\mathrm{CH})$ screening using thyroid stimulating hormone (TSH) is being done worldwide but the cutoff values vary widely in different countries and is influenced by perinatal factors [1-3]. We aimed to analyze the TSH value distribution in venous blood sampled for newborn screening and to identify the perinatal factors influencing it.

This retrospective observational study was done between January 2014 and June 2019 in south India. Newborns with their TSH screening value available were included. Babies who were $<33 \mathrm{wk}$ and $<1500 \mathrm{~g}$ were excluded. Venous blood TSH cut-off $<10 \mathrm{mIU} / \mathrm{L}$ was considered screen negative. Institutional ethical committee approved the study.

Among a total of 15,586 babies born, analysis was done with 14,738 babies. Median gestational age and birth weight were 38 wk (37-39) and $2950 \mathrm{~g}$ (2670-3230), respectively. There were $51.5 \%$ male, $89.2 \%$ term babies, and $61.5 \%$ vaginally born. Median TSH value was $2.81 \mathrm{mIU} / \mathrm{L}$ with 95 th percentile of $11.33 \mathrm{mIU} / \mathrm{L}$. A higher median TSH value was seen in term babies $(p<0.001)$, vaginal birth $(p<0.001)$, male gender $(p<0.001)$, birth weight $\geq 2500 \mathrm{~g}(p<0.004)$ and babies sampled at $24-47 \mathrm{~h}$ of life $(p<0.001)$. Majority of population ( $88 \%$ ) was represented by term babies between 48 and $96 \mathrm{~h}$ of life and this subset of population had a median $\mathrm{TSH}$ value of $2.85 \mathrm{mIU} / \mathrm{L}(1.42,5.41)$ with 95 th percentile being $11.33 \mathrm{mIU} / \mathrm{L}$.

Ramesh Srinivasan

drsramesh95@gmail.com

1 Department of Pediatrics, PSG Institute of Medical Sciences and Research, Coimbatore, Tamil Nadu 641004, India

2 Department of Community Medicine, PSG Institute of Medical Sciences and Research, Coimbatore, Tamil Nadu, India

3 Department of Biochemistry, PSG Institute of Medical Sciences and Research, Coimbatore, Tamil Nadu, India
$1072(7.2 \%)$ babies were screen positive and 19 were confirmed to have $\mathrm{CH}$. Since our TSH screening cutoff was $<10$ $\mathrm{mIU} / \mathrm{L}$ but 95th percentile in our study was $11.33 \mathrm{mIU} / \mathrm{L}$, we followed up babies with TSH value between 10 and 11.33 mIU/L. Among 339 babies with TSH between 10 and 11.33 $\mathrm{mIU} / \mathrm{L}$, follow-up was available for 305 (90\%). Repeat TSH at 2 wk of age was normal for 118 babies (34.8\%). Parents were contacted for 187 babies (55.2\%), aged 1-6 y and were reported to be normal.

A TSH screening cutoff of $>11.33 \mathrm{mIU} / \mathrm{L}$ may be considered as an appropriate threshold for babies screened with venous blood between 48 and $96 \mathrm{~h}$ of age. In our study population this would have resulted in $31.6 \%$ reduction in recall rate without missing a case of $\mathrm{CH}$. However a large-scale prospective population-based study is needed.

\section{Compliance with Ethical Standards}

Conflict of Interest None.

\section{References}

1. American Academy of Pediatrics, Rose SR, Section on Endocrinology and Committee on Genetics, American Thyroid Association, Brown RS, Public Health Committee, Lawson Wilkins Pediatric Endocrine Society, Foley T, et al. Update of newborn screening and therapy for congenital hypothyroidism. Pediatrics. 2006;117:2290-303.

2. Sudhanshu S, Riaz I, Sharma R, Desai MP, Parikh R, Bhatia V. Newborn screening guidelines for congenital hypothyroidism in India: recommendations of the Indian Society for Pediatric and Adolescent Endocrinology (ISPAE) - part II: imaging, treatment and follow-up. Indian J Pediatr. 2018;85:448-53.

3. Léger J, Olivieri A, Donaldson M, et al. European Society for Paediatric Endocrinology consensus guidelines on screening, diagnosis, and management of congenital hypothyroidism. Horm Res Paediatr. 2014;81:80-103.

Publisher's Note Springer Nature remains neutral with regard to jurisdictional claims in published maps and institutional affiliations. 